\title{
34. SEISMIC PROPERTIES OF SERPENTINIZED PERIDOTITE FROM THE MARIANA FOREARC ${ }^{1}$
}

\author{
Dean M. Ballotti, ${ }^{2}$ Nikolas I. Christensen, ${ }^{2}$ and Keir Becker ${ }^{3}$
}

\begin{abstract}
Compressional and shear velocities, density, and porosity were measured for 22 serpentinized peridotites recovered during ODP Leg 125. The densities of the samples vary from 2.40 to $2.86 \mathrm{~g} / \mathrm{cm}^{3}$, whereas the compressional velocities at $200 \mathrm{MPa}$ are between 4.60 and $6.47 \mathrm{~km} / \mathrm{s}$. A positive linear trend exists between both compressional and shear velocities and density. The high porosity in serpentinized peridotites decreases the density and seismic velocity.
\end{abstract}

\section{INTRODUCTION}

The role of serpentinized peridotite in the seismic and petrologic nature of the oceanic crust and upper mantle has not been clearly established. Since Hess (1962) proposed that serpentinized peridotite might account for a wide range of velocities in the crust, there has been a great deal of controversy regarding these rocks in the literature. Although Cann (1968), Oxburgh and Turcotte (1968), and Christensen (1970) argued convincingly against the ubiquitous serpentinization of the crust, serpentinized peridotites are known to be common in areas of fracture zones, transform faults, and subduction zones (e.g., Aumento and Loubat, 1971; Bonatti and Honnorez, 1976). Interest in the distribution of serpentinite within the oceanic crust was rejuvenated after the recovery of serpentinized peridotites at Holes 779A, 780C, and 784A during Leg 125 of the Ocean Drilling Program (ODP).

Two seamounts were drilled during Leg 125: Conical Seamount in the Mariana forearc and Torishima Forearc Seamount in the Izu-Bonin forearc. These seamounts are thought to have formed by an upwelling and extrusion of hydrated mantle material that contained serpentine sediments and more competent blocks of variably serpentinized peridotite. The seamounts are associated with fracture zones, which because of high fluid content in the downgoing slab act as conduits for mantle material moving upward during diapirism. At Hole $779 \mathrm{~A}$, which is located halfway up the southeast flank of Conical Seamount, $319.2 \mathrm{~m}$ was cored with $22.9 \%$ recovery. The recovered samples consist of blocks of variably serpentinized harzburgite and dunite embedded in a matrix of serpentine sediment. Drilling at Hole 780C penetrated $163.5 \mathrm{~m}$ into the summit of Conical Seamount, with only $8.8 \%$ recovery of serpentinized peridotites, which are similar to samples from Hole 779A. Drilling at Hole 784A, located north of Conical Seamount along the inner wall of the Izu-Bonin Trench on the western flank of Torishima Forearc Seamount, penetrated $425.3 \mathrm{~m}$ with $51.3 \%$ recovery. The serpentinized blocks found in the lower sections of this hole are set in a sheared and brecciated serpentine sediment.

In this study, we examine the seismic properties of the variably serpentinized peridotites recovered at Holes 779A, 780C, and 784A. The seismic velocities of these rocks, when compared with seismicrefraction velocities, place constraints on crustal composition. Birch (1960) and Christensen (1966) presented the initial data for the seismic and physical properties of the serpentinized peridotites. Lab-

\footnotetext{
'Fryer, P., Pearce, J. A., Stokking, L. B., et al., 1992. Proc. ODP, Sci. Results, 125: College Station, TX (Ocean Drilling Program).

${ }^{2}$ Dept. of Earth and Atmospheric Sciences, Purdue University, West Lafayette, IN 47906, U.S.A.

${ }^{3}$ Rosenstiel School of Marine and Atmospheric Science, University of Miami, 4600 Rickenbacker Causeway, Miami, FL 33149, U.S.A.
}

oratory-measured seismic velocities and density can be used to calculate elastic constants, which provide additional information about the nature of the oceanic crust. For example, Christensen (1972) compared laboratory measurements of Poisson's ratio with seismicrefraction values to argue that the oceanic crust is unlikely to contain abundant serpentine. Here, we present the compressional and shear velocities for 22 samples of variably serpentinized peridotite.

\section{LABORATORY TECHNIQUES}

Twenty-two 2.5 -cm-diameter minicores were taken normal to the core sections for velocity measurements. The samples were selected from the least weathered sections and were immediately sealed in water for shipment to the laboratory. The samples were trimmed and polished to right circular cylinders with flat, parallel ends. Sample density was determined from the volume and saturated weight. The samples were then jacketed in copper foil, with a 100-mesh screen placed between the sample and jacket. The screen allows any water trapped in the void space to escape without building pore pressure. Care was taken to maintain the saturated state of the samples until after the velocity runs were finished. The samples were then carefully dried and weighed, and the porosity calculated from the wet and dry weights.

Compressional and shear velocities were measured using the pulse transmission technique (Birch, 1960; Christensen, 1985) to hydrostatic pressures of $200 \mathrm{MPa}$, which is equivalent to the pressure approximately $7 \mathrm{~km}$ below the seafloor. Compressional and shear waves were generated by transducers having a $1-\mathrm{MHz}$ resonant frequency. Velocities were measured as a function of confining pressure to $200 \mathrm{MPa}$ in steps of $10 \mathrm{MPa}$. Figure 1 is a typical plot of velocity at elevated confining pressures (Sample 125-779A-14R-2, $54-56 \mathrm{~cm}$ ). The velocities are reported from least-squares-curve-fit data (Wepfer and Christensen, 1988). The estimated error in the velocities is $\pm 0.5 \%$ for $V_{p}, \pm 1 \%$ for $V_{s}$, and $\pm 6 \%$ for Poisson's ratio (Christensen and Shaw, 1970).

\section{EXPERIMENTAL RESULTS}

Velocities as a function of confining pressure and bulk density are tabulated in Table 1 . The values of porosity, $\mathrm{V}_{p} / \mathrm{V}_{s}$, and Poisson's ratio at $200 \mathrm{MPa}$ that were calculated from these velocities are reported in Table 2. It is crucial to note that because the velocities were measured in only one direction (normal to the core), the values of Poisson's ratio in Table 2 may have significant errors. Serpentinized peridotites are commonly highly anisotropic as a result of the preferred orientation of relic olivine (Birch, 1961; Christensen, 1966). For anisotropic materials, velocities averaged in three orthogonal directions are frequently used to calculate Poisson's ratio. One-half of the recovered core is archived; consequently, there is often not enough rock to obtain three orthogonal samples for velocity measurements. 
Table 1. Density and compressional and shear velocities to $250 \mathrm{MPa}$ of Leg 125 serpentinized peridotites.

\begin{tabular}{|c|c|c|c|c|c|c|c|c|c|c|}
\hline \multirow{2}{*}{$\begin{array}{l}\text { Core, section, } \\
\text { interval }(\mathrm{cm})\end{array}$} & \multirow{2}{*}{$\begin{array}{l}\text { Density } \\
\left(\mathrm{g} / \mathrm{cm}^{3}\right)\end{array}$} & \multirow[b]{2}{*}{ Mode } & \multicolumn{8}{|c|}{ Velocity $(\mathrm{km} / \mathrm{s})$ at } \\
\hline & & & $20 \mathrm{MPa}$ & $40 \mathrm{MPa}$ & $60 \mathrm{MPa}$ & $80 \mathrm{MPa}$ & $100 \mathrm{MPa}$ & $150 \mathrm{MPa}$ & $200 \mathrm{MPa}$ & $250 \mathrm{MPa}$ \\
\hline \multicolumn{11}{|l|}{$125-779 A-$} \\
\hline \multirow[t]{2}{*}{$5 R-1,46-48$} & \multirow[t]{2}{*}{2.641} & $P$ & 5.943 & 5.972 & 5.996 & 6.008 & 6.017 & 6.035 & 6.047 & 6.057 \\
\hline & & $S$ & 3.196 & 3.260 & 3.293 & 3.301 & 3.304 & 3.307 & 3.308 & 3.309 \\
\hline \multirow[t]{2}{*}{$5 R-2,26-28$} & \multirow[t]{2}{*}{2.526} & $P$ & 5.381 & 5.406 & 5.430 & 5.447 & 5.460 & 5.490 & 5.515 & 5.535 \\
\hline & & $S$ & 2.967 & 2.988 & 3.005 & 3.013 & 3.019 & 3.028 & 3.033 & 3.037 \\
\hline \multirow[t]{2}{*}{$8 \mathrm{R}-1,39-41$} & \multirow[t]{2}{*}{2.733} & $P$ & 5.859 & 5.907 & 5.946 & 5.966 & 5.982 & 6.014 & 6.038 & 6.057 \\
\hline & & $S$ & 3.259 & 3.293 & 3.316 & 3.324 & 3.328 & 3.334 & 3.336 & 3.338 \\
\hline \multirow[t]{2}{*}{$8 R-1,74-76$} & \multirow[t]{2}{*}{2.858} & $P$ & 6.254 & 6.321 & 6.379 & 6.406 & 6.424 & 6.452 & 6.465 & 6.473 \\
\hline & & $S$ & 3.405 & 3.443 & 3.467 & 3.475 & 3.479 & 3.484 & 3.486 & 3.487 \\
\hline \multirow[t]{2}{*}{$10 \mathrm{R}-2,150-151$} & \multirow[t]{2}{*}{2.557} & $P$ & 5.395 & 5.434 & 5.470 & 5.489 & 5.505 & 5.534 & 5.552 & 5.565 \\
\hline & & $S$ & 2.872 & 2.900 & 2.918 & 2.925 & 2.928 & 2.932 & 2.934 & 2.936 \\
\hline \multirow{2}{*}{$11 R-1,87-89$} & \multirow[t]{2}{*}{2.544} & $P$ & 5.348 & 5.418 & 5.479 & 5.509 & 5.531 & 5.570 & 5.594 & 5.610 \\
\hline & & $S$ & 2.774 & 2.800 & 2.821 & 2.829 & 2.834 & 2.839 & 2.841 & 2.842 \\
\hline \multirow[t]{2}{*}{$12 \mathrm{R}-1,33-35$} & \multirow[t]{2}{*}{2.575} & $P$ & 5.732 & 5.767 & 5.800 & 5.817 & 5.831 & 5.855 & 5.870 & 5.880 \\
\hline & & $S$ & 2.960 & 2.976 & 2.991 & 2.999 & 3.005 & 3.015 & 3.021 & 3.024 \\
\hline $13 R-2,47-49$ & 2.719 & $P$ & 5.523 & 5.568 & 5.611 & 5.632 & 5.648 & 5.672 & 5.682 & 5.687 \\
\hline & & $S$ & 3.042 & 3.068 & 3.087 & 3.095 & 3.100 & 3.105 & 3.106 & 3.106 \\
\hline $14 R-2,54-56$ & 2.864 & $P$ & 6.139 & 6.189 & 6.233 & 6.255 & 6.271 & 6.296 & 6.310 & 6.319 \\
\hline & & $S$ & 3.322 & 3.373 & 3.400 & 3.407 & 3.411 & 3.416 & 3.419 & 3.421 \\
\hline $125-780 \mathrm{C}$. & & & & & & & & & & \\
\hline $3 R-1,14-16$ & 2.761 & $P$ & 6.046 & 6.072 & 6.102 & 6.121 & 6.139 & 6.178 & 6.211 & 6.238 \\
\hline & & $S$ & 3.331 & 3.348 & 3.364 & 3.373 & 3.380 & 3.396 & 3.408 & 3.417 \\
\hline $6 \mathrm{R}-1,34-36$ & 2.576 & $P$ & 5.343 & 5.407 & 5.464 & 5.493 & 5.515 & 5.551 & 5.571 & 5.585 \\
\hline & & $S$ & 2.811 & 2.858 & 2.899 & 2.900 & 2.906 & 2.913 & 2.916 & 2.918 \\
\hline $6 \mathrm{R}-1,78-80$ & 2.649 & $P$ & 5.828 & 5.864 & 5.896 & 5.915 & 5.930 & 5.963 & 5.988 & 6.009 \\
\hline & & $S$ & 3.019 & 3.043 & 3.062 & 3.069 & 3.074 & 3.081 & 3.084 & 3.086 \\
\hline $9 R-1,53-55$ & 2.560 & $P$ & 5.366 & 5.413 & 5.455 & 5.479 & 5.499 & 5.541 & 5.573 & 5.598 \\
\hline & & $S$ & 2.802 & 2.828 & 2.853 & 2.866 & 2.875 & 2.891 & 2.899 & 2.905 \\
\hline $12 \mathrm{R}-1,44-46$ & 2.396 & $P$ & 4.386 & 4.447 & 4.500 & 4.527 & 4.547 & 4.582 & 4.603 & 4.618 \\
\hline & & $s$ & 2.492 & 2.526 & 2.555 & 2.570 & 2.580 & 2.598 & 2.608 & 2.615 \\
\hline 18R-1, 37-39 & 2.661 & $P$ & 5.463 & 5.539 & 5.608 & 5.644 & 5.672 & 5.722 & 5.752 & 5.772 \\
\hline & & $S$ & 2.971 & 2.999 & 3.021 & 3.029 & 3.034 & 3.039 & 3.040 & 3.040 \\
\hline $18 \mathrm{R}-1,118-120$ & 2.745 & $P$ & 5.865 & 5.895 & 5.926 & 5.944 & 5.960 & 5.995 & 6.023 & 6.045 \\
\hline & & $S$ & 3.205 & 3.219 & 3.231 & 3.237 & 3.242 & 3.251 & 3.257 & 3.262 \\
\hline $125-784 \mathrm{~A}-$ & & & & & & & & & & \\
\hline $40 \mathrm{R}-2,29-31$ & 2.473 & $P$ & 4.533 & 4.583 & 4.629 & 4.657 & 4.681 & 4.733 & 4.774 & 4.809 \\
\hline & & $S$ & 2.548 & 2.579 & 2.599 & 2.606 & 2.610 & 2.615 & 2.617 & 2.619 \\
\hline $45 \mathrm{R}-1,39-42$ & 2.462 & $P$ & 5.030 & 5.049 & 5.070 & 5.082 & 5.094 & 5.117 & 5.133 & 5.145 \\
\hline & & $S$ & 2.521 & 2.632 & 2.674 & 2.682 & 2.685 & 2.686 & 2.687 & 2.687 \\
\hline $45 \mathrm{R}-1,64-67$ & 2.553 & $P$ & 5.608 & 5.639 & 5.670 & 5.688 & 5.704 & 5.737 & 5.762 & 5.782 \\
\hline & & $S$ & 2.993 & 3.006 & 3.017 & 3.023 & 3.028 & 3.037 & 3.043 & 3.047 \\
\hline $45 R-1,114-117$ & 2.652 & $P$ & 5.523 & 5.558 & 5.593 & 5.615 & 5.633 & 5.671 & 5.699 & 5.721 \\
\hline & & $S$ & 2.958 & 2.993 & 3.023 & 3.037 & 3.047 & 3.063 & 3.070 & 3.075 \\
\hline $45 R-2,13-16$ & 2.669 & $P$ & 5.713 & 5.738 & 5.762 & 5.776 & 5.788 & 5.814 & 5.835 & 5.851 \\
\hline & & $S$ & 3.051 & 3.091 & 3.120 & 3.132 & 3.140 & 3.152 & 3.158 & 3.162 \\
\hline $45 \mathrm{R}-2,44-47$ & 2.658 & $P$ & 5.672 & 5.711 & 5.747 & 5.767 & 5.784 & 5.820 & 5.845 & 5.864 \\
\hline & & $s$ & 3.028 & 3.066 & 3.101 & 3.118 & 3.131 & 3.152 & 3.164 & 3.170 \\
\hline
\end{tabular}

\section{DISCUSSION}

Serpentinized peridotites were recovered during Deep Sea Drilling Project (DSDP) Legs 37, 45, and 82 and ODP Legs 103, 107, and 109 (Juteau et al., 1990). The stratigraphic position of the serpentinized peridotites from Legs $37,45,82,107$, and 109 indicates that these rocks were exposed at one time in, or adjacent to, an active volcanic zone, presumably an axial valley. The serpentinized peridotites recovered during Leg 125 are different from similar rocks that were collected during the previous legs in that these rocks outcrop in a forearc region.

Hyndman (1976) and Christensen (1976) reported compressional velocities of serpentinized peridotites from Leg 37 . The Leg 37 serpentinized peridotites had densities of between 2.644 and $2.836 \mathrm{~g} / \mathrm{cm}^{3}$ and compressional velocities at $200 \mathrm{MPa}$ between 6.31 and $6.96 \mathrm{~km} / \mathrm{s}$. Schreiber and Rabinowitz (1979) reported compressional velocities of serpentinized peridotites recovered during Leg 45 . These rocks had densities of between 2.54 and $2.72 \mathrm{~g} / \mathrm{cm}^{3}$ and compressional velocities from 5.30 to $5.42 \mathrm{~km} / \mathrm{s}$ at $200 \mathrm{MPa}$. Goldberg and Zinszner (1988) also reported compressional velocities as a function of effective pressure of serpentinized peridotites cored during Leg 103.

Figure 2, a plot of density vs. compressional and shear velocities at $200 \mathrm{MPa}$ for the Leg 125 samples, shows a positive linear trend between density and velocity. However, as Christensen and Salisbury (1975) pointed out, velocity-density proportionalities are valid only for specific rock types. The density and velocities at $200 \mathrm{MPa}$ of samples from Legs 37 and 45 fall into the range of density and velocities at $200 \mathrm{MPa}$ of the Leg 125 samples. Samples to the left of the dashed line in Figure 2 have a density of less than $2.55 \mathrm{~g} / \mathrm{cm}^{3}$, the density of minerals of the serpentine group (Deer et al., 1966). These low densities are related to significant porosity (up to $11 \%$; Table 2) in the cores selected for velocity measurements. 


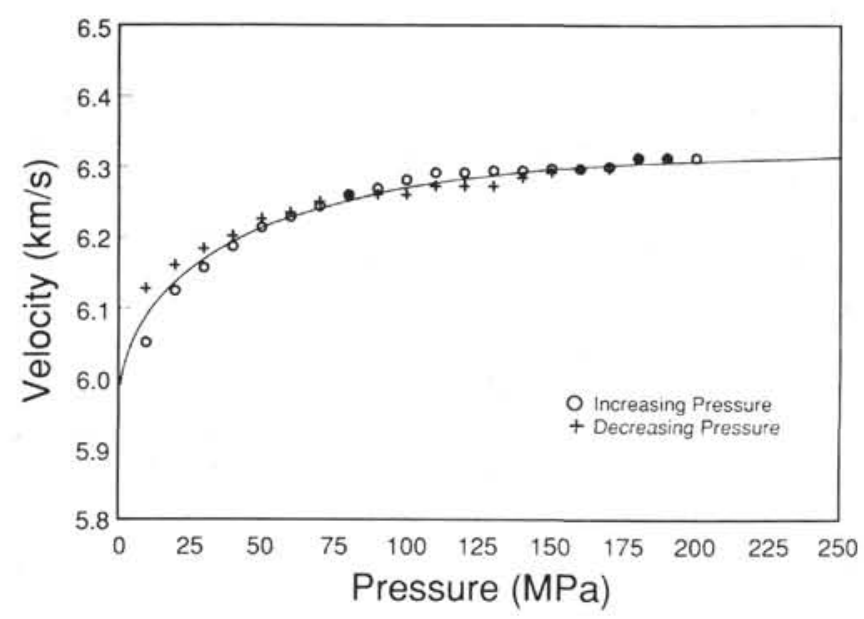

Figure 1. Typical data plot of confining pressure vs. compressional velocity for Sample 125-779A-14R-2, 54-56 cm. Curve fit of Wepfer and Christensen (1988).

A plot of density vs. porosity for nine of the low-density serpentinites (Fig. 3) shows that density decreases with increasing porosity. The ranges of density and compressional velocity in serpentinized peridotite are commonly attributed to the variable hydration of olivine, which results in a reduction in density from 3.3 to $2.55 \mathrm{~g} / \mathrm{cm}^{3}$. However, Figure 3 reveals that porosity may also play a role in the variable velocity of serpentinized peridotite.

Poisson's ratio is useful for studying the Earth's crust because it is determined from only the compressional and shear velocities. For relatively pure serpentinites, Poisson's ratio usually falls between 0.35 and 0.38 (Christensen, 1966, 1972). However, values of Poisson's ratio for the Leg 125 samples are low (between 0.26 and 0.33 ). In Figure 4, Poisson's ratio is shown vs. porosity for the nine

Table 2. Porosity, $\mathbf{V}_{p} / V_{s}$, and Poisson's ratio at 200 MPa of Leg 125 serpentinized peridotites.

\begin{tabular}{|c|c|c|c|}
\hline $\begin{array}{l}\text { Core, section, } \\
\text { interval }(\mathrm{cm})\end{array}$ & $\begin{array}{c}\text { Porosity } \\
(\%)\end{array}$ & $V_{p} / V_{x}$ & $\begin{array}{l}\text { Poisson's } \\
\text { ratio }\end{array}$ \\
\hline \multicolumn{4}{|l|}{$125-779 \mathrm{~A}-$} \\
\hline $5 R-1,46-48$ & 0.5 & 1.828 & 0.29 \\
\hline $5 R-2,26-28$ & 1.0 & 1.818 & 0.29 \\
\hline $8 \mathrm{R}-1,39-41$ & 0.2 & 1.810 & 0.28 \\
\hline $8 \mathrm{R}-1,74-76$ & 0.3 & 1.855 & 0.30 \\
\hline $10 \mathrm{R}-2,150-151$ & 0.7 & 1.892 & 0.31 \\
\hline IIR-1, $87-89$ & 0.8 & 1.969 & 0.33 \\
\hline $12 \mathrm{R}-1,33-35$ & 0.5 & 1.943 & 0.32 \\
\hline $13 R-2,4-49$ & 0.1 & 1.830 & 0.29 \\
\hline $14 \mathrm{R}-2,54-56$ & 0.2 & 1.846 & 0.29 \\
\hline \multicolumn{4}{|l|}{$125-780 \mathrm{C}-$} \\
\hline $3 R-1,14-16$ & 0.2 & 1.822 & 0.28 \\
\hline $6 \mathrm{R}-1,34-36$ & 0.9 & 1.910 & 0.31 \\
\hline $6 \mathrm{R}-1,78-80$ & 0.4 & 1.942 & 0.32 \\
\hline $9 \mathrm{R}-1,53-55$ & 0.8 & 1.922 & 0.31 \\
\hline $12 \mathrm{R}-1,44-46$ & 10.9 & 1.765 & 0.26 \\
\hline $18 \mathrm{R}-1,37-39$ & 0.7 & 1.892 & 0.31 \\
\hline $18 \mathrm{R}-1,118-120$ & 0.5 & 1.849 & 0.29 \\
\hline \multicolumn{4}{|l|}{$125-784 \mathrm{~A}-$} \\
\hline $40 \mathrm{R}-2,29-31$ & 4.8 & 1.824 & 0.29 \\
\hline $45 \mathrm{R}-1,39-42$ & 5.8 & 1.910 & 0.31 \\
\hline $45 \mathrm{R}-1,64-67$ & 2.9 & 1.894 & 0.31 \\
\hline $45 \mathrm{R}-1,114-117$ & 0.4 & 1.856 & 0.30 \\
\hline $45 R-2,13-16$ & 0.2 & 1.847 & 0.29 \\
\hline $45 \mathrm{R}-2,44-47$ & 0.2 & 1.847 & 0.29 \\
\hline
\end{tabular}

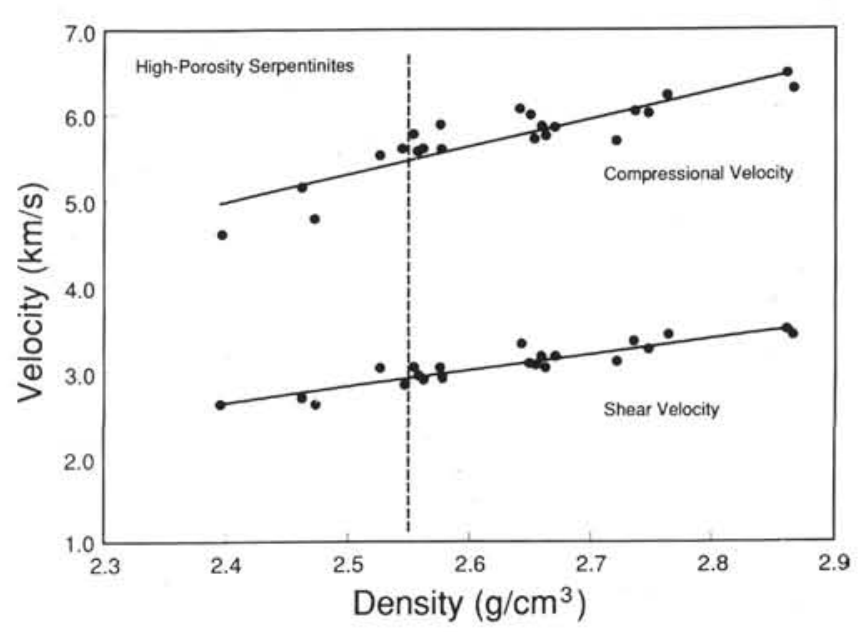

Figure 2. Compressional and shear velocities at $200 \mathrm{MPa}$ as a function of density of the Leg 125 serpentinized peridotites. Solid lines through the data are the least-squares solutions. To the left of the dashed line are the low-density, high-porosity samples.

low-density samples. The horizontal error bars were estimated by assuming accuracies of $0.5 \%$ and $1 \%$ for $\mathrm{V}_{p}$ and $\mathrm{V}_{s}$, respectively (Christensen and Shaw, 1970). Figure 4 shows a trend of decreasing Poisson's ratio with increasing porosity. Therefore, porosity affects Poisson's ratio, as it does density and velocity. An examination of Figure 2 suggests that for samples with a density less than $2.55 \mathrm{~g} / \mathrm{cm}^{3}$ porosity decreases affect the compressional velocity relatively more than the shear velocity, thus lowering Poisson's ratio.

An examination of thin sections shows that samples with a density less than $2.60 \mathrm{~g} / \mathrm{cm}^{3}$ consist almost entirely of serpentine. Hence, density variations for these samples are likely porosity related. Hyndman and Drury (1976), in a study of the physical properties of Leg 37 basalts, claimed that the high porosity resulted in a low Poisson's ratio in oceanic basalts, whereas Francis (1976) suggested that high porosity increases Poisson's ratio. The trend of the Leg 125 samples supports the conclusions of Hyndman and Drury, although porosity may affect the Poisson's ratio of basalts differently than that of serpentinites. It is interesting that the increasing porosity can, in some cases, lower Poisson's ratio whereas in other cases it can raise Poisson's ratio. Theoretical models of cracked media (Shearer, 1988) indicate that this difference can be explained in terms of the aspect ratio of the cracks: thin cracks with aspect ratios less than $1 / 200$ will generally increase Poisson's ratio, whereas thick cracks with aspect ratios between $1 / 20$ and $1 / 2$ will decrease Poisson's ratio. Electron microscope images of the pore structure of the Leg 125 serpentinites could possibly serve as a definitive test of this theory.

\section{CONCLUSIONS}

Serpentinized peridotites recovered from Leg 125 fall into two groups: samples with a density greater than $2.55 \mathrm{~g} / \mathrm{cm}^{3}$ and relatively low porosity and those with a density less than $2.55 \mathrm{~g} / \mathrm{cm}^{3}$ and higher porosity. Compressional velocities of the Leg 125 serpentinized peridotites that have a density greater than $2.55 \mathrm{~g} / \mathrm{cm}^{3}$ are within the range of density and compressional velocities of previous studies of serpentinized peridotites. A linear trend exists between density and both compressional and shear velocities.

Samples with a density less than $2.55 \mathrm{~g} / \mathrm{cm}^{3}$ are anomalous with respect to seismic velocity and Poisson's ratio. Porosity in these samples decreases both density and seismic velocities. In addition, high porosity also decreases Poisson's ratio. The results presented here demonstrate the important effect of porosity on the physical properties of oceanic serpentinite. 


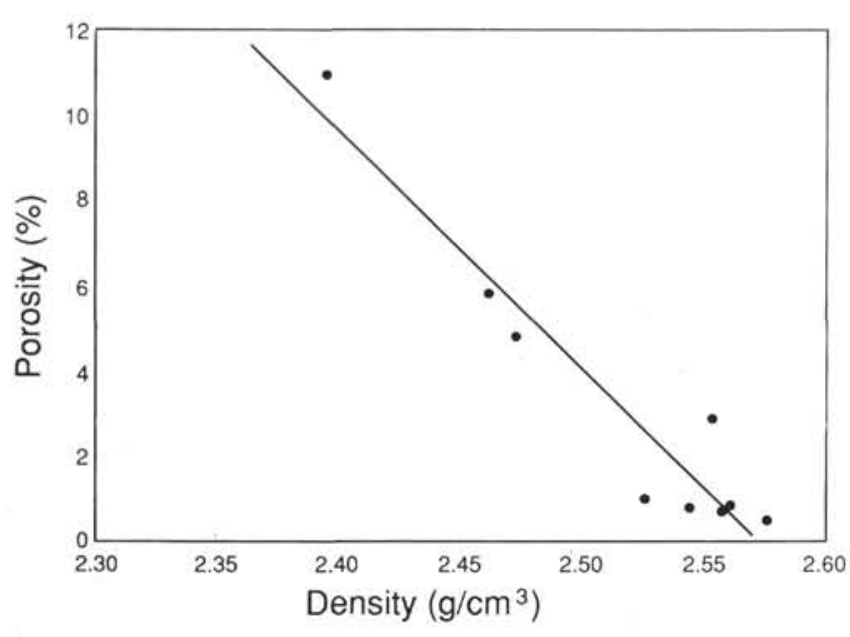

Figure 3. Density-porosity plot of the nine low-density, high-porosity samples. The solid line is the least-squares solution.

\section{REFERENCES}

Aumento, F., and Loubat, H., 1971. The Mid-Atlantic Ridge near $45^{\circ} \mathrm{N}$. XVI. Serpentinized ultramafic intrusions. Can. J. Earth Sci., 8:631-663.

Birch, F., 1960. The velocity of compressional waves in rocks to 10 kilobars, 1. J. Geophys. Res., 65:1083-1102.

-1961 . The velocity of compressional waves in rocks to 10 kilobars, 2. J. Geophys. Res., 66:2199-2224.

Bonatti, E., and Honnorez, J., 1976. Sections of the Earth's crust in equatorial Atlantic. J. Geophys. Res., 81:4104-4116.

Cann, J. F., 1968. Geological processes at mid-mean ridge crests. Geophys. J. R. Astron. Soc., 15:331-341.

Christensen, N. L, 1966. Elasticity of ultrabasic rocks. J. Geophys. Res., 71:5921-5931.

, 1970. Composition and evolution of the oceanic crust. Mar. Geol., 8:139-154

, 1972. The abundance of serpentinites in the oceanic crust. J. Geol., 80:709-719.

, 1976. Seismic velocities of DSDP Leg 37 rocks and their geophysical implications. In Aumento, F., Melson, W. G., et al., Init. Repts. DSDP, 37: Washington (U.S. Govt. Printing Office), 389-401.

, 1985. Measurements of dynamic properties of rocks at elevated temperatures and pressures. In Pincus, H. J., and Hoskins, E. R. (Ed.), Measurements of Rock Properties at Elevated Pressures and Temperatures: Philadelphia (Am. Soc. for Testing and Materials), ASTM STP 869:93-107.

Christensen, N. I., and Salisbury, M. H., 1975. Structure and constitution of the lower oceanic crust. Rev. Geophys. Space Phys., 13:57-86.

Christensen, N. I., and Shaw, G. H., 1970. Elasticity of mafic rocks from the Mid-Atlantic Ridge. Geophys. J. R. Astron. Soc., 20:271-284.

Deer, W. A., Howie, R. A., and Zussman, J., 1966. An Introduction to the Rock Forming Minerals: New York (Longman).

Francis, T.J.G., 1976. The ratio of compressional to shear velocity and rock porosity on the axis of the Mid-Atlantic Ridge. J. Geophys. Res., 81:4361-4364.

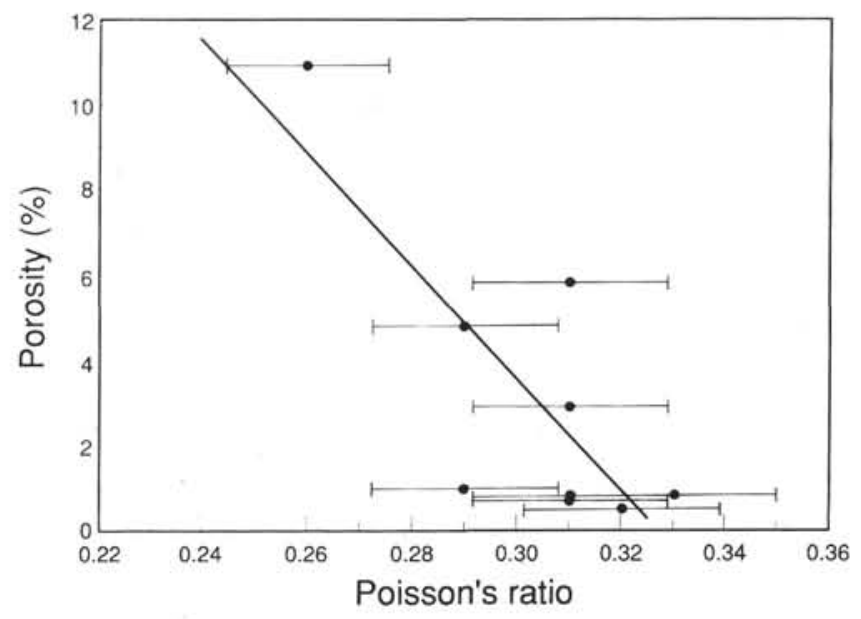

Figure 4. Poisson's ratio-porosity plot of the nine low-density, high-porosity samples. The solid line represents the least-squares solution. Horizontal error bars are based on a $6 \%$ error.

Goldberg, D., and Zinszner, B., 1988. Acoustic properties of altered peridotite at Site 637 from laboratory and sonic waveform data. In Boillot, G., Winterer, E. L., et al., Proc. ODP, Sci. Results, 103: College Station, TX (Ocean Drilling Program), 269-276.

Hess, H. H., 1962. History of ocean basins. In Engel, A.E.J., James, H. L., and Leonard, B. F. (Eds.), Petrologic Studies: A Volume in Honor of A. F. Buddington: Geol. Soc. Am., 599-620.

Hyndman, R. D., 1976. Seismic velocity measurements of basement rocks from DSDP Leg 37. In Aumento, F., Melson, W. G., et al., Init. Repts. DSDP, 37: Washington (U.S. Govt. Printing Office), 373-387.

Hyndman, R. D., and Drury, M. J., 1976. The physical properties of oceanic basement rocks from deep drilling on the Mid-Atlantic Ridge. J. Geophys. Res., 81:4042-4052.

Juteau, T., Cannat, M., and Lagabrielle, Y., 1990. Serpentinized peridotites in the upper oceanic crust away from transform zones: a comparison of the results of previous DSDP and ODP Legs. In Detrick, R., Honnorez, J., Bryan, W. B., Juteau, T., et al. Proc. ODP, Sci. Results, 106/109: College Station, TX (Ocean Drilling Program), 303-308.

Oxburgh, E. R., and Turcotte, D. L., 1968. Mid-ocean ridges and geotherm distribution during mantle convection. J. Geophys. Res., 73:2643-2661.

Schreiber, E., and Rabinowitz, P. D., 1979. Acoustic wave velocity measurements of oceanic crustal samples-DSDP, Leg 45. In Melson, W. G., Rabinowitz, P. D., et al., Init. Repts. DSDP, 45: Washington (U.S. Govt. Printing Office), 383-386.

Shearer, P. M., 1988. Cracked media, Poisson's ratio and the structure of the upper oceanic crust. Geophys. J., 92:357-362.

Wepfer, W. W., and Christensen, N. I., 1988. Characterizing microcracks via a velocity pressure relation. Eos, 68:1503.

Date of initial receipt: 8 October 1990

Date of acceptance: 12 June 1991

Ms 125B-161 